\title{
NATURAL ALTERNATIVE REMEDIES IN THE BACKGROUND OF UPDATED RECOMMENDATIONS FOR THE PROPHYLACTIC AND THERAPEUTIC APPROACH OF CLOSTRIDIUM DIFFICILE INFECTIONS
}

\author{
MARA GEORGESCU ${ }^{1 \#}$, OCTAV GINGHINÄ ${ }^{2,3 * *}$, ȘTEFANIA RAITA ${ }^{1 \#}$, DANA TĂPĂLOAGĂ ${ }^{1 \#,}$ \\ LUCIAN ILIE $^{1 \#}$, CAROLINA NEGREI $^{2 \#}$, DANIELA ELENA POPA ${ }^{2 \#}$, VALENTIN VARLAS $^{2 \#}$, \\ RĂZVAN MULȚESCU ${ }^{3 \#}$, ADRIAN COSMIN ROȘCA ${ }^{4 \#}$, RADU MIRICÁ $^{3 \#}$, DRAGOȘ GEORGESCU ${ }^{2,3 \#}$ \\ ${ }^{1}$ University of Agronomic Sciences and Veterinary Medicine of Bucharest, 59 Mărăşti Boulevard, 011464, Bucharest, Romania \\ ${ }^{2}$ University of Medicine and Pharmacy "Carol Davila" Bucharest, 37 Dionisie Lupu Street, Bucharest, Romania \\ 3 "Sf. Ioan" Clinical Emergency Hospital, 13 Vitan Bărzești Highway, Bucharest, Romania \\ 4 “Ovidius” University, 6 Căpitan Av. Al. Șerbănescu Street, Campus, Corp C, Constanța, Romania
}

*corresponding author: octavginghina@gmail.com

\#All authors have equal contribution.

Manuscript received: February 2018

\begin{abstract}
Clostridium difficile infection (CDI) remains one of the greatest concerns in current worldwide medical practice. Its incidence, severity and patient susceptibility range have known a steady growth. The antibiotics of choice are associated with increasing recurrence rates, decreased susceptibility for some strains, the selection of other antibiotic-resistant enteric pathogens and high cost of treatment, difficult to be supported by the healthcare system. Even if there is a general agreement over the first choice CDI treatment options, the most important international guidelines are not consistent regarding alternative treatment options, such as probiotics, intravenous immunoglobulins (IVIG), monoclonal antibodies, novel antibiotics (fidaxomicin), most of which remaining controversial. Upon consulting international guidelines, numerous discordant recommendations and unsolved issues are revealed. These differences may be due to the constant evolution of prevention and management strategies, in the background of emergence of new scientific and novel treatment suggestions. Many efforts are targeting the discovery of an ideal CDI treatment approach, which would not only eliminate the bacteria and reduce its toxin production, but also achieve restoration of beneficial intestinal microflora and assist the patient immune system. Therefore, many off-label, experimental, novel, natural or combination solutions have been addressed in the latest published research on this matter. In order to assist the potential guidance of future research in this field, this study reviews the recent literature findings on alternative CDI treatment and prophylaxis options.
\end{abstract}

\section{Rezumat}

Infecția cu Clostridium difficile rămâne o problemă dificilă a practicii medicale curente pe plan mondial. Incidența şi severitatea bolii, precum și susceptibilitatea pacienților au cunoscut o creștere semnificativă. Antibioterapia este asociată cu o creștere a ratei de recurență post-terapie, cu o scădere a sensibilității pentru anumite tulpini, cu selecția altor patogeni intestinali antibio-rezistenți, dar și cu un cost ridicat, dificil de suportat de către sistemele de sănătate. Deși există un oarecare consens în ceea ce privește terapia de primă linie, cele mai importante ghiduri internaționale nu sunt concordante în ceea ce privește alternativele terapeutice cum ar fi folosirea probioticelor, a imunoglobulinelor administrare intravenos, a anticorpilor monoclonali, a noilor antibiotice (fidaxomicina), cele mai multe dintre ele fiind încă subiect de controversă. Studiul ghidurilor internaționale a relevat multiple discordanțe și aspecte nerezolvate. Aceste diferențe pot fi explicate prin evoluția constantă a strategiilor de prevenire și tratament, pe fondul progreselor științifice și a apariției a unor noi metode terapeutice. Eforturile sunt îndreptate spre găsirea unui tratament optim al infecției cu Clostridium difficile care să asigure nu numai eliminarea bacteriilor și reducerea producției de toxină, ci și refacerea microflorei intestinale și echilibrarea sistemului imun al pacientului. Astfel, în literatura de specialitate au fost descrise numeroase alternative terapeutice off-label, experimentale, de fitoterapie. Pentru a contribui la o posibilă orientare a recomandărilor viitoare în acest domeniu, acest studiu trece în revistă atât recomandările actuale, cât și ultimele cercetări publicate avînd ca subiect alternativele de tratament și profilaxie a infecției cu C. difficile.

Keywords: Clostridium difficile infection (CDI), CDI treatment, CDI prophylaxis, adjunctive/alternative treatments, natural remedies

\section{Introduction}

Clostridium difficile infection (CDI) is presently one of the most increasingly diagnosed re-emerging health- care associated problem and vastly gaining in importance in worldwide medical practice, as driven by higher incidence and severity over the last decades. To respond to this constant trend and current emergence 
FARMACIA, 2018, Vol. 66, 4

of BI/NAP1/027, PCR ribotype 078 [17] and other hipervirulent $C$. difficile strains, the rising shift in asymptomatic carriage, significant rates of recurrence and continuous extending of susceptible population profile, treatment and prevention options are steadily developed.

\section{Current guidelines for CDI treatment}

\section{IDSA-SHEA}

Before 2018, according to IDSA and SHEA recommendations (the Infectious Diseases Society of America and Society for Healthcare Epidemiology of America, respectively), metronidazole used to be considered the drug of choice for the treatment of initial mild to moderate CDI episode, usually administered orally in $500 \mathrm{mg}$ doses given 3 times per day for 10 - 14 days, whereas vancomycin was primarily elected for initial severe CDI episode (125 mg given orally 4 times per day, for $10-14$ days). Since the publication in February 2018 of the updated recommendations [39], metronidazole has ceased to be indicated as first therapeutic option in adults, with IDSA-SHEA recommendation of vancomycin or fidaxomicin regard-less of CDI severity. Before 2018, in complicated cases (ileus) metronidazole could be associated with vancomycin (either orally or per rectum). Anyway, given its cumulative neurotoxicity potential, metronidazole was only recommended for the first CDI recurrence and not for long term therapy. However, even the new guidelines stress the possibility to use metronidazole when vancomycin or fidaxomicin treatment is not feasible.

Probiotics were not recommended for the prevention of CDI, as numerous drawbacks are still associated with studies which support the effectiveness of probiotics in CDI prevention, such as the diversity of probiotic products, lack of standardization, variation in bacterial counts during storage, small number of patients in trials, exclusion of patients receiving high risk antibiotics from trials etc. Nevertheless, IDSASHEA always suggested larger trials before use of probiotics in CDI prevention can be recommended. Even the new guidelines stress that lack of evidence for efficiency prevents recommendations for probiotics use.

\section{ACG - American College of Gastroenterology}

The American College of Gastroenterology recommends the same treatment options as IDSA-SHEA before 2018 , in the same dosages for moderate to severe CDI as the IDSA-SHEA [65]. However, due to its toxicity, ACG recommends that metronidazole is interrupted after 5 - 7 of failure to therapy. In addition to the two antibiotics, ACG is making conditional recommendation for faecal microbiota transplant (FMT), in case of multiple recurrences. Also, the ACG maintains that, despite moderate indications of
Lactobacillus rhamnosus GG and Saccharomyces boulardii ability to decrease the incidence of antibiotic associated diarrhoea, insufficient evidence is yet available in support of probiotics for prevention of infection with $C$. difficile. Nevertheless, ACG only moderately recommends the use of probiotics to decrease new episodes in patients with recurrent Clostridium difficile infection (RCDI). An additional option according to ACG could be intravenous immune globulin (IVIG), but only for patients with hypo-gammaglobulinaemia.

The ESCMID - the European Society of Clinical Microbiology and Infectious diseases

The ESCMID also still recommends oral metronidazole and oral vancomycin as commonly used antibiotics for CDI treatment [16]. In addition to IDSA-SHEA and ACG guidelines, the ESCMID brings to attention emerging problems related to both antibiotics: vancomycin may be associated with high risk of vancomycin resistant enterococci (VRE) selection and transmission, while metronidazole is increasingly associated with evidence of reduced susceptibility in some $C$. difficile strains, eventhough larger study groups are required to prove this. Therefore, the ESCMID recommends use of two additional antibiotics, fidaxomicin and teicoplanin, with similar or superior efficiency against CDI, as vancomycin, but less likelihood of reported VRE associations. Teicoplanin is known as an antimicrobial glycopeptide acting against Gram-positive anaerobes, some authors also considering its activity against $C$. difficile just as efficient as that of vancomycin or metronidazole [54]. Its limitations to severe repeated recurrences of CDI are related to the high cost.

Regarding alternative treatment regimens, the ESCMID makes IVIG recommendations similar to those of ACG, stating that IVIG therapy could be useful for the subgroup of patients with CDI associated with hypogammaglobulinaemia following solid organ transplant. Regarding the insufficient evidence for potential probiotic efficiency in CDI prophylaxis, the ESCMID is calling for caution in probiotics use, citing evidence of invasive disease associated with use of Saccharomyces boulardii, and reports of increased probiotic associated increased mortality in randomised control acute pancreatitis trial. The ESCMID recommends for FMT following antibiotic treatment in case of multiple RCDI. The ESCMID concludes for insufficient evidence in support of resort to probiotics, toxin-binding resins and polymers, or monoclonal antibodies to alternatively treat CDI.

The WSES (World Society of Emergency Surgery) The WSES makes the same recommendations for metronidazole and vancomycin, as ACG and the ESCMID, while fidaxomicin is recommended for patients with higher recurrence, as an alternative agent [57]. Unlike the other cited guidelines which plead 
FARMACIA, 2018, Vol. 66, 4

for insufficient evidence supporting probiotics use in CDI treatment or even call for caution due to reported systemic disease and high mortality, WSES recommends probiotics to be considered for immunocompetent patients with RCDI. Similarly to the ESCMID and the ACG, the WSES recommends FMT and additionally, intestinal microbiota transplantation (IMT) as adjunctive treatment to antibiotics for RCDI treatment, or for immunocompromised patients or patients with solid organ transplants. WSES recommends intravenous immunoglobulin (IVIG) for multiple RCDI or fulminant CDI. Unlike THE ESCMID, which invokes insufficient evidence for monoclonal antibodies recommendation of use, WSES states that infusion with monoclonal antibodies could be used in RCDI, especially in cases with hypervirulent $C$. difficile strains such as 027 . WSES makes no recommendations for probiotics use in CDI treatment.

The ASID (Australasian Society for Infectious Diseases) The ASID still maintain metronidazole and vancomycin as first choice anti-biotherapy, with similar recommendations as the other cited guidelines [66]. Fidaxomicin is strongly recommended as newer therapy, with certain benefits in addition to existing treatment, however not recommended as first therapeutic option because of uncertain cost effectiveness relative to metronidazole and vancomycin. The ASID also recommends FMT only for recurrent or refractory disease. In addition to teicoplanin, also mentioned by the ESCMID, the ASID also recommends fusidic acid and tigecycline, but not as first-line therapy. ASID also mentions rifaximin as alternative option, but not as first-line therapy. Monoclonal antibodies, also recommended by the WSES, are indicated by the ASID only as adjunctive therapy for RCDI prevention. Due to promising in vitro or animal studies, the ASID mentions several new possible agents to be considered for CDI treatment, but does not make recommendations for use because of insufficient or no published clinical trials: cadazolid (an oxazolidinonetype antibiotic), auranofin (2,3,4,6-tetra-o-acetyl-1-thio$\beta$-D-glycopyranp-sato-S-(triethyl-phosphine)-gold (i.e. a gold based product for rheumatoid arthritis therapy), ramoplanin (a glycolipodepsipeptide with vancomycin-like action on bacterial cell walls), surotomycin (a cyclicliopeptide), thuricin CD (a new class of post-translationally modified bacteriocin).

The Sub-commission of Microbial Resistance Control, the Public Health Division, the Romanian Ministry of Health (RMoH)

The recommendations of the Sub-commission of Microbial Resistance Control, the Public Health Division, the Romanian Ministry of Health $(\mathrm{RMoH})$ are different from those of the IDSA-SHEA but are similar to those of the ACG, the ESCMID and the WSES, stating that metronidazole should be the firstchoice option for mild CDI, whereas vancomycin should be administered in severe cases, or as the first option for second or higher recurrences [49]. The $\mathrm{RMoH}$ recommends the use of fidaxomicin only for CDI induced by ribotypes other than 027 and does not recommend its use in Romania, since most CDI cases in Romania are caused by 027 ribotype. The $\mathrm{RMoH}$ provides additional reasons for not recommending fidaxomicin use in Romania, such as lack of timely possibility of 027 ribotype exclusion from CDI cases in most clinics, insufficient evidence for safety of use in severe complications (e.g., toxic megacolon) and the cost of treatment. The $\mathrm{RMoH}$ is against probiotics use in acute CDI, because of reported risk of bacterial or fungal systemic disease.

Eventhough there is an agreement upon the commonly used first-choice treatment antibiotics, the six cited guidelines are not consistent throughout the recommendations regarding the adjuvant or alternative treatment options. The indications considering the use of prophylactic probiotics are significantly different among guidelines, varying from recommended in certain groups of patients with RCDI only for prevention of recurrence (the WSES), to caution in use (the ESCMID), not recommended due to insufficient evidence (the IDSA-SHEA, the ACG) or even against use in acute CDI (the RMoH). Such contradictions concern other alternative treatment options, such as IVIG, monoclonal antibodies and even fidaxomicin. As previously described, fidaxomicin acceptance remains highly controversial, ranging from strong recommendation by most of the international guidelines (the ESCMID, the ASID, the WSES), to advice against recommendation (the $\mathrm{RMoH}$ ). Fidaxomicin is recommended due to a number of efficiency benefits and is considered equally effective or even superior to vancomycin in certain aspects. There are reports indicating that fidaxomicin may result in lower environmental Clostridium difficile contamination, also bearing highly desired positive impact on in-hospital spread of spores [9]. The $\mathrm{RMoH}$ advises against use of fidaxomicin in Romania, due to several reasons among which cost of treatment, or insufficient evidence for safety of use in severe complications. Most new agents reported as promising solutions, by the six sources, could not be included in the guidelines recommendations because of insufficient or lack of clinical trial data or insignificance of data related to the study group size.

Recent publications compared and summarized the content of the five international guidelines discussed above, except for the Romanian guide, revealing discordant recommendations, numerous controversies and unsolved issues on numerous topics regarding CDI management [19]. These differences mainly derive from constant development of prevention and treatment strategies and emergence of further scientific evidence and innovative suggestions for treatment. 


\section{Alternative, off-label and emerging CDI therapeutic options}

Other antibiotic compounds. Rifamycins, especially rifamixin, commonly used as an antituberculosis agent, have been proposed as chaser therapy for $C$. difficile [4]; however, prior exposure may reasonably pose the risk of rifamixin-resistant $C$. difficile emergence. Recent publications indicate a number of novel antimicrobial substances for CDI treatment, currently undergoing clinical trial, among which: ramoplanin, surotomycin, a new cadazolid (oxazolidinone-fluoroquinolone), ridinilazole [54]. However, even if efficacy is shown to be similar to first choice antibiotics, the phase II or III clinical trials conducted so far have failed to prove ramoplanin or surotomycin noninferiority [54].

Intestinal microbiota transplantation (IMT) is also cited in current international guidelines as adjunctive treatment option for advanced CDI [61], but important limitations have been reported, such as reluctance of both patients and physicians, the risk of spreading other infections (HIV and hepatitis) and the risk of dramatic microbiota change, which may increase susceptibility to obesity or autoimmune conditions [4]. DNA vaccination. The immunogenicity of candidate antigens in animals is currently tested for high-level antibody responses, which will allow producing of sub-unit based recombinant toxin proteins, as vaccines. Monoclonal antibodies, also mentioned by current guidelines, but not recommended because of insufficient clinical trial evidence of effectiveness, can be produced by animal or human volunteers who received terminal regions of $C$. difficile toxins. Several receptor-binding regions of $C$. difficile $\mathrm{A}$ and $\mathrm{B}$ toxins $(\mathrm{N}$-terminal or $\mathrm{C}$-terminal regions) are considered candidates for protective antibody responses [4]. Considering significant recent progress in toxin specific monoclonal antibodies technology, researchers report opportunities for further studying and optimization of immunization approaches for CDI treatment and prophylaxis [4]. Bacteriophages. There are studies indicating that the ability of several specific $C$. difficile bacteriophages to significantly decrease $C$. difficile count and reduce toxin production both in remedial and prophylactic treatment [54]. Nevertheless, there are indications that bacteriophage-resistant colonies may emerge after initial reduction of bacterial load [54].

Bacteriocins. GE2270, nisin, lacticin 3147, Thuricin CD, actagardine, LFF571 and diffocin antimicrobial activity has been brought to our attention by recent studies which highlight the efficacy of such bacteriocins in preclinical, as well as clinical studies [54].

Toxin binding agents. Several compounds have been discussed in relation to CDI treatment or prophylaxis. Cholestyramine, one of the first agents to be tested for effectiveness against recurrent $\mathrm{CDI}$, is an ion exchange resin, proposed as CDI prophylaxys in patients on systemic antibiotic therapy [51]. Tolevamer, a polymer with toxin-binding activity, of lower efficacy against $C$. difficile than first choice antibiotics, is nevertheless helpful in lowering the recurrence rates of CDI, more than vancomycin or metronidazole [20]. An additional toxin-binding compound proved effective in sequestering $C$. difficile toxins is calcium aluminosilicate anti-diarrheal (CASAD), a naturally occurring clay known for its cation exchange absorbent related ability [64]. Although deemed a promising adjuvant agent in CDI therapy, no proof could be obtained in clinical trials, because of unsuccessful enrolment.

Bile Acids Therapy. The intestinal composition of bile acid plays a notable role in prevention of $C$. difficile spore germination and growth and certain bile acids, such as ursodeoxycholic acid, have accordingly been proven effective [70], in their inhibition. A further compound, CamSA (a taurocholate analogue) was shown to inhibit $C$. difficile germination [28] and also to efficiently achieve dose-dependent CDI prophylaxis in preclinical studies [27]. However, recent reviews of research activity in the field indicate that it remains unclear whether bile acids and their analogues could be considered for CDI prevention or adjunct treatment [20]. Premature toxin activators. Ivarsson ME et al [31] have proposed an inositol hexakisphosphate (IPS) analogue (INS-5010) as premature toxin activator agent in a preclinical study on $C$. difficile infected mice, proving improvement of histological signs compared to control subjects. This compound was developed from IP6, a natural substance found in all eukaryotic cells, considered the main phosphorous storage source in plant seeds, constituting $2 \%$ of the dry weight of common grains and FDA-granted Generally Recognized as Safe (GRAS) compound status [30]. Nevertheless, Inositec AG, the company which develops INS-5010 is still seeking to partner certain drug candidate and discovery assets, not having moved on to clinical trials so far [30].

Intestinal Antibiotic Inactivators. One of the major risks, unanimously recognised as intimately associated with CDI development, is systemic antibiotic induced disrupter of intestinal microbiota balance. Therefore, protecting this balance by eliminating antibiotic therapy effect means eliminating one of the major CDI risks. There are some products that literature indicates to inactivate systemic antibiotics that reach the colon, through various mechanisms:

(1) DAV132 - a product based on activated-charcoal, provided with enteric coating and able to absorb antibiotics (e.g., amoxicillin or moxifloxacin) from the proximal colon [15]. DAV132 efficiently prevented moxifloxacin-induced CDI in hamsters [40].

(2) $\mathrm{SYN}-004$ is a recombinant beta-lactamase product, inactivating parenteral beta-lactam antibiotics on reach into the intestine. A recent study [34] proved effective ceftriaxone inactivation by $\mathrm{SYN}-004$ in dog intestine, 
with antibiotic serum levels remaining unchanged. This product also proved valuable after clinical trial testing [53].

(3) Cephalosporinase-producing Bacteroides thetaiotaomicron was used in a study for the inactivation of parenteral administered ceftriaxone which reaches the intestine [63]. The study reveals successful protection of normal intestine microbiota and protection against CDI and also vancomycinresistant Enterococcus spp. in mice model.

Marine Mammal Microbiota able to produce novel antibiotic agents effective against $C$. difficile. In a study of intestinal microorganisms in five marine mammals, Ochoa JL et al [45] have identified a Micromonospora strain which proved selective activity against various Gram-positive pathogens without possessing any human cytotoxicity. The authors isolated phocoenamicin, a novel complex glycosylated polyketide with anti $C$. difficile antimicrobial activity. Using fluorescence imaging and flow cytometry, Ochoa JL et al [45] confirmed that phocoenamicin can shift the membrane potential leaving membrane integrity unaltered.

Insect peptide coprisine. An antibacterial peptide isolated from Copristripartitus, a Korean dung beetle, coprisine, includes a nine amino-acid peptide with antimicrobial activity in its helical region (LLCIA LRKK) [29]. In a study on a mouse model with experimental induced CDI, Jin Ku Kang et al [32] examined the possibility for a coprisin analogue (a disulphide dimer of the nine peptides) to prevent $C$. difficile infection induced inflammation and mucosal damage. The authors revealed that coprisine analogue treatment is associated with improved survival rate, decreased inflammation response and mucosal damage. A further positive aspect communicated by the same researchers is the lack of antibiotic activity of coprisine analogue, on commensal bacteria such as Lactobacillus and Bifidobacterium [32]. These findings suggest that the coprisine analogue should be considered as a good candidate for alternative treatment and prophylaxis of CDI.

\section{Natural products as promising alternative and adjunctive options}

Disputed recommendations of current international guidelines on CDI treatment derived from controversies and unsolved issues in the context of constant increase of incidence and severity of CDI cases, call for intensive research for the development of alternative treatment options. Currently, the commonly accepted and recommended conventional antibiotic treatment choices for CDI, are very limited. Even though the excessive and widespread use of antibiotics is being condemned worldwide, it remains a common practice which is still linked with the development of antibiotics resistance in many pathogens. This problem is especially dangerous for infections such as CDI, for which the available treatment choices are limited from the beginning [62]. Natural remedies have been used since ancient times as cures for diseases and are currently the sources of a significant part of modern drugs. Therefore, natural-, plant- or animal-derived remedies, used as alternative or adjunctive treatment or prophylaxis become desirable options to prevent and contain $C$. difficile resistance and provide safe and effective therapy.

\section{Virgin coconut oil}

Shilling M. [59] has recently published a study evaluating the lipidic components of virgin coconut oil in terms of antibacterial activity against $C$. difficile. The authors have assessed the in vitro antimicrobial effect of whole virgin coconut oil, specifically the effect against $C$. difficile of its most important individual fatty acids, reporting that lauric acid (C12) revealed the most intensive inhibitory action, by reduction of $\mathrm{CFU} / \mathrm{mL}$. Other fatty acids, such as capric and caprylic acids (C10 and $\mathrm{C} 8$, respectively) exhibited lower inhibitory activity, whereas whole coconut oil only exhibited antimicrobial action against $C$. difficile, when lipolyzed and used in $0.15-1.2 \%$ concentration. Furthermore, using electron transmission microscopy, the authors reported that disruption of cell membrane and cytoplasm of $C$. difficile strains is the mechanism by which medium-chain fatty acids from virgin coconut oil (lauric acid $2 \mathrm{mg} / \mathrm{mL}$ ), exert their antibacterial effect. The results of this study are intensively cited and positively appreciated by other researchers [3, 4]. Coconut oil was also reported to exhibit in vitro antifungal activity comparable with chlorhexidine and ketoconazole, in a study using $C$. albicans isolated from tooth surfaces of children with early childhood caries [60].

The antibacterial effect of coconut oil has been extensively studied and is nowadays acknowledged against pathogens such as L. monocytogenes [36], Streptococcus mutans [47], Streptococcus pyogenes [43].

In more recent studies, other authors confirm the inhibitory effect of virgin coconut oil (VCO) free fatty acids (FFA) against pathogens like Bacillus subtilis (ATCC 11774), Escherichia coli (ATCC 25922), Salmonella enteritidis (ATCC 13076) and Staphylococcus aureus (ATCC 25923) [44]. The authors used Candida rugosa lipase (CRL) to obtain the coconut oil free fatty acids and performed hydrolysis at 1:5 w/w VCO to buffer ratio, $1.5 \% \mathrm{w} / \mathrm{w}$ oil $\mathrm{CRL}, \mathrm{pH}=7$ and $40^{\circ} \mathrm{C}$. However, the authors revealed that only FFA exhibited inhibition against the tested pathogens, while the residual hydrolysed virgin coconut oil and the whole VCO did not present any antibacterial activity. Similar conclusions were drawn by Nagase S. [43], who demonstrated that eventhough whole 
FARMACIA, 2018, Vol. 66, 4

virgin coconut oil has antimicrobial effect against Streptococcus spp., no activity was noticed against $S$. aureus or Gram-negative bacteria. The same authors proved that lauric acid (50\% of virgin coconut oil fatty acids) has different antimicrobial spectrum, exhibiting antimicrobial activity against $S$. aureus, towards which virgin coconut oil has no effect. Furthermore, the authors reveal stronger antimicrobial effect of lauric acid against several Streptococcus species, in comparison with coconut oil. Based on such results, the need becomes apparent to test coconut oil antimicrobial activity on separate fatty acids to achieve targeted antibacterial action. This approach could be useful for an efficient antibacterial evaluation of coconut oil components against Clostridium spp.

\section{Pomegranate extracts (Punica granatum L.)}

The antimicrobial activity of pomegranate extract was reported against several pathogens such as Propionibacterium granulosum, Staphylococcus aureus and Staphylococcus epidermidis [35], as well as against Salmonella enteritidis, Listeria monocytogenes, E. coli and Yersinia enterocolitica, due to its peel high content $(262.5 \mathrm{mg} / \mathrm{g})$ in active inhibitors (phenolics, flavonoids) [5].

In a very recent publication [18], the authors report the possibility to attribute pomegranate antimicrobial activity to ellagitannins (ETs), a class of hydrolysable tannins (HT) including over 500 different compounds. The authors indicate that ETs are known to be found only in dycotyledonous angiosperms and they are commonly consumed along with some of their hydrolysis products (such as ellagic acid), in fruits, nuts and their processed products. Pomegranate includes two main types of ETs, namely punicalagins and punicalins. This study indicates that $250 \mathrm{~mL}$ pomegranate juice could provide $0.05 \% \mathrm{w} / \mathrm{W}$ punicalagins in the colon. By in vitro exposure of intestinal Clostridium spp. bacteria to punicalagins and punicalins, it was reported that the inhibition ranges from $26 \%$ to $100 \%$, depending on the Clostridium species. The authors also mark that ETs from pomegranate exhibit inhibition activity towards pathogenic bacteria, without adverse effects on the beneficial bacteria and furthermore, even favouring Lactobacillus spp. bacteria growth [18]. Similar results are communicated by Finegold S.M. et al [20], which revealed that pomegranate extract exhibits MICs ranging from 12.5 to $25 \mathrm{mg} / \mathrm{mL}$ gallic acid equivalent range, against toxigenic $C$. difficile strains.

\section{Angelica archangelica L. (Apiaceae)}

A study by a group of Italian researchers on the chemical composition and supposed antimicrobial activity of Angelica archangelica L. (Apiaceae) root essential oil has revealed significant activity against C. difficile, C. perfringens, E. faecalis, Eubacterium limosum, Peptostreptococcus anaerobius and Candida albicans (MIC values of $0.25 \%, 0.25 \%, 0.13 \%$, $0.25 \%, 2.25 \%$ and $0.50 \% \mathrm{v} / \mathrm{v}$, respectively) [22]. Effectiveness against these pathogens is even more significant since the antimicrobial activity against the useful microflora is very week (MIC values $>4.0 \%$ v/v against bifidobacteria and lactobacilli) [22].

\section{Nigella sativa and Commiphora myrrha (Myrrh)}

In a study by Khalid M. Aljarallah [33], seeds of black cumin (Nigella sativa) and Commiphora myrrha (Myrrh) were studied as potential inhibitors of $C$. difficile growth. Their antibacterial activity was studies under oil (Nigella sativa) and water extract (Nigella sativa and Myrrh) forms. According to study results, Myrrh water extract and black seed oil (2\%) are similarly effective natural antibacterial agents for inhibition of $C$. difficile growth, in a wide range of environment $\mathrm{pH}$ (4.5 - 7). Khalid M. Aljarallah [33] suggests that Nigella sativa seeds and Commiphora myrrha (Myrrh) should be considered as potential alternative and adjuvant therapy options for the treatment of human CDI. Black cumin seeds have been extensively used as spice and valued for a wide range of pharmacological actions, among which immunity modulator, analgesic, antimicrobial, antiinflammatory, spasmolytic etc. [2, 14, 24]. Many of Nigella sativa therapeutic properties have been attributed to thymoquinone, considered the most significant bioactive component of the essential oil [18]. The antimicrobial effects of Nigella sativa have extensively been studied in vitro $[7,68]$ and in vivo [52] against various microorganisms such as Enterobacteriaceae, Staphylococcus, Streptococcus, Salmonella, Listeria, Helicobacter, Pseudomonas, Klebsiella, Proteus etc. Therefore, including Nigela sativa bioactive compounds in clinical trials for testing the efficiency against CDI would be of interest.

\section{Manuka honey}

Manuka honey is known for its in vitro antimicrobial effect against numerous pathogenic bacteria [23, 37, 58]. Manuka honey stands out among conventional honeys due to its non-peroxide antimicrobial activity, attributed to certain 1,2-dicarbonyl compounds, and especially to methylglyoxal (MGO) [23].

A study by Hammond and Donkor [26], revealed Manuka honey in vitro bactericidal concentrations of $6.25 \%(\mathrm{v} / \mathrm{v})$ for $C$. difficile. A more recent study confirms the $6.25 \%(\mathrm{v} / \mathrm{v})$ MIC and MBC of Manuka honey activity against various $C$. difficile (PCR) ribotypes (RTs) (e.g., RT017, RT023, RT027 and RT046), also showing its ability to effectively inhibit $C$. difficile strains-induced biofilm formation [48]. The study of Piotrowski et al [48] suggests the possibility to successfully use Manuka honey as $C$. difficile spread prevention agent, whereas it's possible use for CDI 
FARMACIA, 2018, Vol. 66, 4

prophylaxis, as well as its efficacy on $C$. difficile spores remain to be investigated further. It is even more important to admit the need to perform clinical trials on Manuka honey to test its efficacy in CDI prevention, especially when honey supplementation in CDI clinical trials has already been tried very recently on patient groups at higher $C$. difficile infection risk. In a cross-sectional study by Mohsen Saleh El Alfy et al [41], on paediatric patients with malignancy, it is revealed that honey supplementation improved the occurrence rate of gastrointestinal complications associated with chemotherapy, reducing the rate of CDI.

\section{Humulus lupulus}

A recent study by Cermak $P$ et al [10] tested the antimicrobial activity against $B$. fragilis, $C$. perfringens and $C$. difficile of hop (Humulus lupulus L.) constituents' humulone, lupulone and xanthohumol. The authors revealed that xanthohumol showed the most relevant antimicrobial effects, with MIC and MBC values of $15-107 \mu \mathrm{g} / \mathrm{mL}$, close to those of conventional antibiotics. Cermak P et al [10] suggest that hop purified compounds may thus be potential alternatives for the treatment of CDI.

\section{Traditional Chinese herbal formulas}

For centuries, Chinese herbal medicines have been used for the treatment of various disorders, including gastrointestinal disease. The effectiveness of Chinese herbal medicines on intestinal bowel disease (IBD) symptoms improvement has been proved in clinical trials conducted two decades ago [8]. The diversity of medicinal plants found around the world is fairly unlimited, but very few have been investigated for their bioactive compounds and far less than that have been actually included in clinical trials [46]. However, recent articles reveal that Chinese medicines such as berberine, can successfully inhibit $C$. difficile and help regulate the intestinal microflora, when prescribed after initial vancomycin treatment [38]. Another example of Chinese medicine tested for efficacy in $C$. difficile associated diarrhoea (CDAD) prevention, is QPYF (consisted of Rhodiola rosea, Poria cocos, Codonopsis pilosula, Atractylodes macrocephala, Radix puerariae, Rhizoma zingiberis and Glycyrrhiza glabra). When administered a week prior to $C$. difficile experimental infection in a mouse model, traditional Chinese medicine QPYF showed effective protection for CDAD, by significantly lowering histopathological scores and toxin production [25].

\section{Various other raw natural compounds and pure compound extracts}

The investigation of the antimicrobial activity against Clostridium difficile in vitro targeted various other natural compounds such as garlic juice, indicated by Roshan N. et al [55], as the most active raw natural products. Moreover, the same study suggested four pure compounds (i.e., trans-cinnamaldehyde, allicin, menthol and zingerone) as the most active processed products against Clostridium difficile. Roshan et al [56] also reveals that, as determined by the fractional inhibitory concentration index and the conventional checkerboard titration method, the combined effect of antibiotics and natural compounds should be considered for future complementary CDI treatments.

Alongside carvacrol (a compound extracted from oregano oil), an additional $C$. difficile related study also mentioned trans-cinnamaldehyde, the most important cinnamon component as a substance able to reduce production of the $C$. difficile toxin and toxin-mediated cell-toxicity $[1,42]$. The same study revealed inhibition of toxin production by a mechanism of downregulation of toxin production genes (global repressor CodY).

Another important aspect is that these compounds do not interfere with intestinal microbiota. Toxin production being a $C$. difficile major virulence factor, such natural plant compounds are promising agents for future development of alternative CDI treatment solutions [1].

In a more recent study, certain commercially available supplements, such as ginger, peppermint oil and aloe vera are indicated as remedies for the symptoms of non-specific inflammatory bowel disease (IBD) [54]. The authors indicate that for the peppermint oil, the improvement of symptoms in IBD patients was proved in placebo-controlled clinical trials. Therefore, further investigation of the antimicrobial properties of peppermint oil against $C$. difficile may be relevant.

\section{Discussion}

The first-choice therapy options for CDI recommended by all international guidelines remain metronidazole and vancomycin. However, numerous drawbacks have been reported, among which the lack of efficiency for some $C$. difficile strains, the increasing recurrence rates, the selection of additional resistant enteric pathogens, the difficult management of complications in patients with associated diseases and other risk category patients. Fidaxomicin, suggested for higher efficiency and compatibility with beneficial microflora survival, is severely restricted by the high cost of treatment. The few other novel antibiotic choices either failed to prove the non-inferiority to first choice option drugs or are under clinical trials. In the last years, insufficient new antibiotics have received approval from clinical trials, despite the significant demand due to increased resistance. The most important 6 international guide-lines are 
inconsistent regarding alternative treatment options. Recommendations for probiotics, FMT, IVIG, monoclonal antibodies and even fidaxomicin, may range from strong recommendation, to advice against use. On the background of such unresolved issues and controversies, research efforts are aiming the ideal treatment option for CDI, which would not only reduce the infectious and toxin burden given by $C$. difficile, but also restore intestinal microbiota and assist patient immune system. Increasing attention is lately awarded to traditional medicine plants, natural vegetal or animal extracts, natural animal derived products, which proved significant efficiency in vitro or in animal model studies, but also considerable efficiency in combinational antibiotic therapies in clinical trials [50]. Among the most popular alternative suggestions for CDI treatment and prevention the latest publications address bacteriophage, toxinbinding agents, premature toxin activators, intestinal antibiotic inactivators, bile acid therapy, animal microbiota compounds, insect extracted compounds, vegetal extracts (roots, leaves, fruits, seeds), animal made products, herbal combinations in traditional Chinese formulas. Many of these natural alternatives achieve selective antimicrobial activity against $C$. difficile, improve clinical signs, reduce complications, protect and restore the beneficial microbiota or achieve effective protection against contamination.

\section{Conclusions}

C. difficile infection is continuing to be a major problem impacting present medical practice, with increasing incidence and severity. Standard treatment recommendations are considered suitable for most CDI cases, yet recurrence rates, complications, treatment options in risk patients and increased prevalence in intensive care units, create difficulties in CDI management and prevention. International guidelines are inconsistent in alternative options recommendations, while continuous research is currently addressing strategies and solutions for treatment and prophylaxis. Many off-label, experimental, novel, natural or combination alternatives are approached in the recent literature. Promising results related to natural compounds and extracts should be considered for future research of combinational antibiotic therapies. Many of these options need further investigation of toxicological profiles, of possible interactions and clinical trial confirmation.

\section{Acknowledgement}

This paper was published with the financial support of FDI grant CNFISFDI-2018-0507, funded by National Council for Higher Education, Ministry of National Education (Romania).

\section{References}

1. Abhinav Upadhyay, Shankumar Mooyottu, Hsinbai Yin, Meera Surendran Nair, Inhibiting Microbial Toxins Using Plant-Derived Compounds and Plant Extracts. Medicines, 2015; 2: 186-211.

2. Ahmad A, Husain A, Mujeeb M, Khan SA, Najmi AK, Siddique NA, A review on therapeutic potential of Nigella sativa: A miracle herb. As Pac J Trop Biomed., 2013; 3(5): 337-352.

3. Aljarallah KM, Conventional and alternative treatment approaches for Clostridium difficile infection. Int $J$ Health Sci., 2017; 11(1): 1-10.

4. Aljarallah KM, Inhibition of Clostridium difficile by natural herbal extracts. J Taibah Univ Med Sci., 2016; 11(5): 427-431.

5. Al-Zoreky NS, Antimicrobial activity of pomegranate (Punica granatum L.) fruit peels. Int $J$ Food Microbiol., 2009; 134(3): 244-248.

6. Andrés-Lasheras S, Bolea R, Mainar-Jaime RC, Kuijper E, Sevilla E, Martín-Burriel I, Presence of Clostridium difficile in pig faecal samples and wild animal species associated with pig farms. $J \mathrm{Appl}$ Microbiol., 2017; 122: 462-472.

7. Bakal SN, Bereswill S, Heimesaat MM, Finding Novel Antibiotic Substances from Medicinal Plants Antimicrobial Properties of Nigella sativa Directed against Multidrug-resistant Bacteria. Eur J Microbiol Immunol. (Bp), 2017; 7(1): 92-98.

8. Bensoussan A, Talley NJ, Hing M, Menzies R, Guo A, Treatment of irritable bowel syndrome with Chinese herbal medicine: a randomized controlled trial. JAMA, 1998; 280(18): 1585-1589.

9. Biswas JS, Patel A, Otter JA, Reduction in Clostridium difficile environmental contamination by hospitalized patients treated with fidaxomicin. $J$ Hosp Infect., 2015; 90: 267-270.

10. Cermak P, Olsovska J, Mikyska A, Dusek M, Kadleckova Z, Vanicek J, Nyc O, Sigler K, Bostikova V, Bostik P. Strong antimicrobial activity of xanthohumol and other derivatives from hops (Humulus lupulus L.) on gut anaerobic bacteria. APMIS, 2017; 125(11): 1033-1038.

11. Chandrabali Ghose, Clostridium difficile infection in the twenty-first century. Emerg Microbes Infect., 2013; 2(9): e62: 1-8.

12. Cheesman MJ, Ilanko A, Blonk B, Cock IE, Developing New Antimicrobial Therapies: Are Synergistic Combinations of Plant Extracts/Compounds with Conventional Antibiotics the Solution? Pharmacog Rev., 2017; 11(22): 57-72.

13. Cohen SH, Gerding DN, Johnson S, Clinical Practice Guidelines for Clostridium difficile Infection in Adults: 2010 Update by the Society for Healthcare Epidemiology of America (SHEA) and the Infectious Diseases Society of America (IDSA). Infect Control Hosp Epidem., 2010; 31(5): 431-455.

14. Dajani EZ, Shahwan TG, Dajani NE, Overview of the preclinical pharmacological properties of Nigella sativa (black seeds): a complementary drug with historical and clinical significance. J Physiol Pharmacol., 2016; 67(6): 801-817. 
FARMACIA, 2018, Vol. 66, 4

15. De Gunzburg J, Ducher A, Modess C, Wegner D, Oswald S, Dressman J, Targeted adsorption of molecules in the colon with the novel adsorbentbased Medicinal Product, DAV132: a proof of concept study in healthy subjects. J Clin Pharmacol., 2015; 55: 10-16.

16. Debast SB, Bauer MP, Kuijper EJ, European Society of Clinical Microbiology and Infectious Diseases: update of the treatment guidance document for Clostridium difficile infection. Clin Microb Infect., 2014; 20: 1-26.

17. Dubberke ER, Carling P, Carrico R, Donskey CJ, Loo VG, McDonald C, Strategies to Prevent Clostridium difficile Infections in Acute Care Hospitals: 2014 Update. Infect Control Hosp Epidemiol., 2014; 35(6): 628-645.

18. Elhadi M Yahia, Fruit and vegetable phytochemicals. Chemistry and Human Health. $2^{\text {nd }}$ Ed, Vol. 1, Part 1, Chapter 13.6, Wiley Blackwell. John Wiley and Sons. Ltd. 2018.

19. Fehér C, Mensa J, A Comparison of Current Guidelines of Five International Societies on Clostridium difficile Infection Management. Infect Dis Therapy, 2016; 5(3): 207-230.

20. Finegold SM, Summanen PH, Corbett K, Downes J, Henning SM, Li Z, Pomegranate extract exhibits in vitro activity against Clostridium difficile. Nutrition, 2014; 30(10): 1210-1212.

21. Florescu SA, Nedelcu NI, Calistru PI, Petruc F, Ceaușu E, Significant decreasing of the systemic antibiotics' consumption associated with antimicrobial stewardship intervention conducted in infectious diseases university hospital from Eastern Europe. Farmacia, 2017; 65(3): 356-359.

22. Fraternale D, Flamini G, Ricci D, Essential oil composition and antimicrobial activity of Angelica archangelica L. (Apiaceae) roots. J Med Food., 2014; 17(9): 1043-1047.

23. Georgescu M, Dobrea M, Dobrea VC, Antimicrobial effect of commercial Manuka honey and conventional local honey against Gram-negative and Gram-positive bacteria. Sci Works (Series C. Vet Med.), 2017; LXIII(2): 133-136.

24. Gholamnezhad Z, Havakhah S, Boskabady MH, Preclinical and clinical effects of Nigella sativa and its constituent, thymoquinone: A review. J Ethnopharmacol., 2016; 190: 372-386.

25. Guo Ya-Nan, Wang Jun, Zhang Hao-Jun, Jia HongBing, Traditional chinese medicine QPYF as preventive treatment for Clostridium difficile associated diarrhea in a mouse model. Evid Based Complemen Altern Med., 2016; 2016(Art. 3759819): 1-7.

26. Hammond EN, Donkor ES, Antibacterial effect of Manuka honey on Clostridium difficile. BMC Res Notes, 2013; 6(188): 1-5.

27. Howerton A, Patra M, Abel-Santos E, A new strategy for the prevention of Clostridium difficile infection. J Infect Dis., 2013; 207: 1498-1504.

28. Howerton A, Ramirez N, Abel-Santos E, Mapping interactions between germinants and Clostridium difficile spores. J Bacteriol., 2011; 193: 274-282.

29. Hwang Jae-Sam, Juneyoung Lee, Yeon-Ju Kim, Isolation and characterization of a defensin-like peptide
(Coprisin) from the dung beetle, Copris tripartitus. Int J Peptides, 2009; 2009(Art. 136284): 1-5.

30. Inositec AG. www.inositec.com.

31. Ivarsson ME, Leroux JC, Castagner B, Investigational new treatments for Clostridium difficile infection. Drug Discov Today, 2015; 20(5): 602-608.

32. Jin Ku Kang, Jae Sam Hwang, Hyo Jung Nam, Keun Jae Ahn, Heon Seok, Sung-Kuk Kim, Eun Young Yun, The Insect Peptide Coprisin Prevents Clostridium difficile-Mediated Acute Inflammation and Mucosal Damage through Selective Antimicrobial Activity. Antimicrob Ag Chemotherapy, 2011; 55(10): 4850-4857.

33. Khalid M. Aljarallah, Inhibition of Clostridium difficile by natural herbal extracts. $J$ Taibah Univ Med Sci., 2016; 11(5): 427-431.

34. Kokai-Kun JF, Bristol JA, Setser J, Schlosser M, Nonclinical safety assessment of SYN-004: an Oral blactamase for the protection of the gut microbiome from disruption by biliary-excreted, intravenously administered antibiotics. Int $J$ Toxicol., 2016; 35: 309-316.

35. Li Z, Summanen PH, Downes J, Corbett K, Komoriya T, Henning SM, Kim J, Finegold SM, Antimicrobial Activity of Pomegranate and Green Tea Extract on Propionibacterium acnes, Propionibacterium granulosum, Staphylococcus aureus and Staphylococcus epidermidis. J Drugs Dermatol., 2015; 14(6): 574-578.

36. Lih Ling Wang, Bao Kang Yang, Kirk L Parkin, Eric A. Johnson, Inhibition of Listeria monocytogenes by monoacylglycerols synthesized from coconut oil and milkfat by lipase-catalyzed glycerolysis. $J$ Agric Food Chem., 1993; 41(6): 1000-1005.

37. Lin SM, Molan PC, Cursons RT, The post- antibiotic effect of Manuka honey on gastrointestinal pathogens. Int $J$ Antimicrob Agents, 2010; 36(5): 467-468.

38. Lv Z, Peng G, Liu W, Xu H, Su J, Berberine blocks the relapse of Clostridium difficile infection in C57BL/6 mice after standard vancomycin treatment. Antimicrob Ag Chemother., 2015; 59(7): 3726-3735.

39. McDonald LC, Gerding DN, Johnson S, Clinical practice guidelines for Clostridium difficile infection in adults and children: 2017 update by the Infectious Diseases Society of America (IDSA) and Society for Healthcare Epidemiology of America (SHEA). Clin Infect Disease., 2018; 66(7): 1-48.

40. Miossec C, Sayah-Janne S, Augustin V, Chachaty E, Weiss W, Pulse M, DAV131, an oral adsorbentbased product, fully protects hamsters against mociflocavin-induced Clostridium difficile lethal infection. Denver: Intersci Conf Antimicrob Agents Chemother, 2013.

41. Mohsen Saleh El Alfy, Iman Ahmed Ragab, Sally Mohamed Saber, Effect of Honey Supplementation on Clostridium Difficile Infection in Childhood Cancer. Egyptian J Hosp Med., 2018; 71(2): 2593-2602.

42. Mooyottu S, Kollanoor-Johny A, Flock G, Bouillaut L, Upadhyay A, Sonenshein AL, Venkitanarayanan $\mathrm{K}$, Carvacrol and trans-cinnamaldehyde reduce Clostridium difficile toxin production and cytotoxicity in vitro. Int J Mol Sci., 2014; 15: 4415-4430.

43. Nagase S, Matsue M, Mori Y, Honda-Ogawa M, Sugitani K, Sumitomo T, Nakata M, Kawabata S, Okamoto S, Comparison of the antimicrobial spectrum 
and mechanisms of organic virgin coconut oil and lauric acid against bacteria. $J$ Welln Health Care, 2017; 41(1): 87-95.

44. Nguyen VTA, Truong Dang Le, Hoa Ngoc Phan, Lam Bich Tran, Antibacterial Activity of Free Fatty Acids from Hydrolyzed Virgin Coconut Oil Using Lipase from Candida rugosa. J of Lipids, 2017; 2017(Art. 7170162): 1-7.

45. Ochoa JL, Sanchez LM, Koo BM, Doherty JS, Rajendram M, Huang KC, Gross CA, Linington RG, Marine Mammal Microbiota Yields Novel Antibiotic with Potent Activity Against Clostridium difficile. ACS Infect Dis., 2018; 4(1): 59-67.

46. Palombo EA, Phytochemicals from traditional medicinal plants used in the treatment of diarrhoea: modes of action and effects on intestinal function. Phytother Res., 2006; 20(9): 717-724.

47. Peedikayil FC, Remy V, John S, Chandru TP, Sreenivasan P, Comparison of antibacterial efficacy of coconut oil and chlorhexidine on Streptococcus mutans: An in vivo study. J Int Soc Prev Com Dent., 2016; 6(5): 447-452.

48. Piotrowski M, Karpiński P, Pituch H, Van Belkum A, Antimicrobial effects of Manuka honey on in vitro biofilm formation by Clostridium difficile. Eur J Clin Microbiol Infect Dis., 2017; 36: 1661-1664.

49. Popescu GA, Szekely E, Codiță I, Tălăpan D, Șerban R, Ruja G, Guidelines for Diagnosis, Treatment and Prevention of Clostridium difficile Infection, $2^{\text {nd }}$ ed., Bucharest, 2016, Sub-commission Of Microbial Resistance Control, Public Health Division, Health Minister of Romania, (available in Romanian).

50. Pop CE, Pârvu M, Arsene AL, Pârvu AE, Vodnar DC, Tarcea M, Toiu AM, Vlase L, Investigation of antioxidant and antimicrobial potential of some extracts from Hedera helix L.. Farmacia, 2017; 65(4): 624-629.

51. Puri BK, Hakkarainen-Smith JS, Monro JA, The potential use of cholestyramine to reduce the risk of developing Clostridium difficile-associated diarrhoea in patients receiving long-term intravenous ceftriaxone. Med Hypotheses, 2015; 84: 78-80.

52. Rafati S, Niakan M, Naseri M, Anti-microbial effect of Nigella sativa seed extract against staphylococcal skin Infection. Med J Islamic Rep Iran, 2014; 28(42): 1-4.

53. Roberts T, Kokai-Kun JF, Coughlin O, Lopez BV, Whalen $\mathrm{H}$, Tolerability and pharmacokinetics of SYN-004, an orally administered b-lactamase for the prevention of Clostridium difficile-associated disease and antibiotic-associated diarrhea, in two phase 1 studies. Clin Drug Investig., 2016; 36: 725-734.

54. Roshan N, Hammer KA, Riley TV, Non-conventional antimicrobial and alternative therapies for the treatment of Clostridium difficile infection. Anaerobe, 2018; 49: 103-111.

55. Roshan N, Riley TV, Hammer KA, Antimicrobial activity of natural products against Clostridium difficile in vitro. J App Microb., 2017; 123(1) 92-103.

56. Roshan N, Riley TV, Hammer KA, Antimicrobial activity of natural products against Clostridium difficile in vitro. J Appl Microbiol., 2017; 123: 92-103.

57. Sartelli M, Malangoni MA, Abu-Zidan FM, WSES (World Society of Emergency Surgery) guidelines for management of Clostridium difficile infection in surgical patients. World J Emerg Surg., 2015; 10(38): 1-23.

58. Sherlock O, Dolan A, Athman R, Power A, Gethin G, Cowman S, Comparison of the antimicrobial activity of Ulmo honey from Chile and Manuka honey against methicillin-resistant Staphylococcus aureus. Escherichia coli and Pseudomonas aeruginosa. BMC Compl Altern Med., 2010; 10(47): 1-5.

59. Shilling M, Matt L, Rubin E, Visitacion MP, Haller NA, Antimicrobial effects of virgin coconut oil and its medium-chain fatty acids on Clostridium diffcile. J Med Food, 2013; 16: 1079-1085.

60. Shino B, Faizal C. Peedikayil, Shyamala R. Jaiprakash, Gufran Ahmed Bijapur, Comparison of Antimicrobial Activity of Chlorhexidine, Coconut Oil, Probiotics, and Ketoconazole on Candida albicans Isolated in Children with Early Childhood Caries: An In Vitro Study. Scientifica, 2016; 2016(Art. 7061587): 1-5.

61. Smith MB, Kelly C, Alm EJ, Policy: How to regulate faecal transplants. Nature, 2014; 506: 290-301.

62. Spigaglia $P$, Recent advances in the understanding of antibiotic resistance in Clostridium difficile infection. Ther Adv Infect Dis., 2016; 3: 23-42.

63. Stiefel U, Nerandzic MM, Pultz MJ, Donskeya CJ, Gastrointestinal colonization with a cephalosporinaseproducing Bacteroides species preserves colonization resistance against vancomycin-resistant Enterococcus and Clostridium difficile in cephalosporin-treated mice. Antimicrob Agents Chemother., 2014; 58: 4535-4542.

64. Sturino JM, Pokusaeva K, Carpenter R, Effective sequestration of Clostridium difficile protein toxins by calcium aluminosilicate. Antimicrob Agents Chemother., 2015; 59: 7178-7183.

65. Surawicz CM, Brandt LJ, Binion DG, Curry SR, Gilligan PH, Guidelines for Diagnosis, Treatment, and Prevention of Clostridium difficile Infections. Am J Gastroenterol., 2013; 108: 478-498.

66. Trubiano JA, Cheng AC, Korman TM, Roder C, Campbell A, May MLA, Blyth CC, Australasian Society of Infectious Diseases updated guidelines for the management of Clostridium difficile infection in adults and children in Australia and New Zealand. Intern Med J., 2016; 46: 479-493.

67. Tsutsumi LS, Owusu YB, Hurdle JG, Sun D, Progress in the Discovery of Treatments for $C$. difficile Infection: A Clinical and Medicinal Chemistry Review. Cur Topics Med Chem., 2014; 14(1): 152-175.

68. Utami AT, Pratomo B, Study of Antimicrobial Activity of Black Cumin Seeds (Nigella sativa L.) Against Salmonella typhi in Vitro. J Med Surg Pathol., 2016; 1(3): 1000127: 1-4.

69. Warriner K, Xu C, Habash M, Sultan S, Weese SJ, Dissemination of Clostridium difficile in food and the environment: Significant sources of $C$. difficile community-acquired infection?. J Appl Microbiol., 2017; 122: 542-553.

70. Weingarden AR, Chen C, Zhang N, Graiziger CT, Dosa PI, Steer CJ, Ursodeoxycholic acid inhibits Clostridium difficile spore germination and vegetative growth, and prevents the recurrence of ilealpouchitis associated with the infection. J Clin Gastroenterol., 2016; 50: 624-630. 